\title{
Use of digital droplet PCR analysis in early diagnostics of winter wheat infection caused by Tilletia spp.
}

\section{Wykorzystanie analizy digital droplet PCR we wczesnej diagnostyce porażenia pszenicy ozimej przez Tilletia spp.}

\author{
Katarzyna Pieczul, Krzysztof Kubiak, Marta Budziszewska, Ilona Świerczyńska*
}

\section{Summary}

The study aimed at using the digital droplet PCR (ddPCR) analysis to identify wheat infection by Tilletia caries (DC.) Tul. and Tilletia laevis Kühn in the early stages of plant development. The tests were carried out on winter wheat, artificially inoculated with $T$. caries and T. laevis teliospores. For the ddPCR tests wheat in development phases BBCH 10-32 and 75 development phases was collected. The ddPCR analysis showed the possibility of identifying pathogen's DNA since the development phase of BBCH 10. In control plants - not infected with Tilletia spp. the presence of fungal DNA was not detected. According to the obtained results, it was also possible to trace the dynamics of pathogen DNA propagation in wheat tissues during a plant development.

Key words: digital droplet PCR, Tilletia spp., common bunt

\section{Streszczenie}

Celem pracy było zastosowanie analizy digital droplet PCR (ddPCR) w celu detekcji porażenia pszenicy przez Tilletia caries (DC.) Tul. oraz Tilletia laevis Kühn, we wczesnych stadiach rozwojowych roślin. Badania prowadzono na pszenicy ozimej, sztucznie inokulowanej teliosporami T. caries oraz T. laevis. Materiał do badań ddPCR pobierano w fazach rozwojowych BBCH 10-32 i 75. Przeprowadzona analiza ddPCR wskazała możliwość detekcji DNA patogenu już od fazy BBCH 10. W roślinach kontrolnych - niezakażanych Tilletia spp. nie wykazano obecności DNA grzyba. Na podstawie uzyskanych wyników możliwe było także prześledzenie dynamiki namnażania DNA patogenu w tkankach pszenicy w trakcie cyklu rozwojowego roślin.

Słowa kluczowe: digital droplet PCR, Tilletia spp., śnieć cuchnąca pszenicy, śnieć gładka pszenicy

\footnotetext{
Instytut Ochrony Roślin - Państwowy Instytut Badawczy

Władysława Węgorka 20, 60-318 Poznań

*corresponding author: i.swierczynska@iorpib.poznan.pl

ORCID: 0000-0002-2922-5962
} 


\section{Wstęp / Introduction}

Śnieć cuchnąca oraz śnieć gładka pszenicy powodowane przez Tilletia caries (DC.) Tul. oraz Tilletia laevis Kühn należą do chorób o bardzo dużej szkodliwości. Zanieczyszczenie ziarna tymi grzybami może stanowić poważny problem zwłaszcza w rolnictwie ekologicznym (Matanguihan i wsp. 2011). Do porażenia roślin dochodzi w początkowej fazie rozwoju pszenicy. Strzępka infekcyjna wnika do rośliny przez koleoptyl, rozwija się w pierwszym liściu, a następnie w stożku wzrostu pędu (Goates 1996; Maksimov i wsp. 2002). Typowe symptomy choroby, wypełnione masą teliospor ziarniaki, widoczne są dopiero po wykłoszeniu (Hoffmann 1982). Niektórzy autorzy obserwowali występowanie plamistości na liściach pszenicy porażonej przez T. caries i T. laevis (Kendrick i Purdy 1959; Dumalasová i Bartoš 2006). W innych badaniach nie potwierdzono jednak korelacji pomiędzy występowaniem plamistości na liściach a porażeniem kłosów przez T. caries. Obserwowano bowiem porażenie kłosów na roślinach bez objawów na liściach, podczas gdy u części roślin z silnymi plamistościami na liściach, nie występowały objawy na kłosach (Josefsen i Christiansen 2002).

Ze względu na brak wyraźnych symptomów chorobowych we wczesnych fazach rozwojowych pszenicy diagnostyka porażenia przez Tilletia spp. jest problematyczna. Patogen należy do organizmów trudnych w standardowej hodowli na sztucznych podłożach, co ogranicza metody detekcji porażenia zasadniczo do analiz molekularnych. Dotychczas w badaniach Tilletia spp. wykorzystywane były różne techniki biologii molekularnej, takie jak: PCR, real-time PCR, izotermiczna amplifikacja kwasów nukleinowych techniką LAMP, pozwalające na detekcję grzyba w tkankach roślin, glebie lub ziarnach pszenicy (McNeil i wsp. 2004; Nian i wsp. 2009; Gao i wsp. 2016; Pieczul i wsp. 2018).

Jedną z innowacyjnych technik, coraz częściej stosowaną w diagnostyce patogenów roślin, jest kropelkowy PCR, digital droplet PCR (ddPCR). Jest to wyjątkowo czuła i precyzyjna technika, oparta na technologii emulsyjno-kropelkowej. Główną zasadą ddPCR jest frakcjonowanie w czasie rzeczywistym mieszaniny reakcyjnej na dziesiątki tysięcy kropli, w których następnie zachodzi reakcja amplifikacji. Dzięki zastosowaniu barwników fluorescencyjnych, bądź też znakowanych sond molekularnych oraz specjalistycznego sprzętu możliwe jest precyzyjne zliczenie kropel pozytywnych (tych, gdzie zaszła reakcja amplifikacji). Z wykorzystaniem modelu statystycznego Poissona obliczana jest liczba kopii badanego genu, bez konieczności odnoszenia się do krzywych standardowych czy genów referencyjnych (Hindson i wsp. 2011; Gutiérrez-Aguirre i wsp. 2015; Koch i wsp. 2016). Technika ddPCR znajduje szerokie zastosowanie m.in. w detekcji patogenów roślin, takich jak: wirusy (Rački i wsp. 2014; Mehle i wsp. 2018, 2020; Pandey i wsp. 2020), bakterie - Xanthomonas citri subsp. citri (Zhao i wsp. 2016), Erwinia amylovora i Ralstonia solanacearum (Dreo i wsp. 2014), Xylella fastidiosa (Dupas i wsp. 2019), Acidovorax citrulli (Lu i wsp. 2020), grzyby - Ilyonectria liriodendri (Del Pilar Martínez-Diz i wsp. 2020), czy też lęgniowce Phytophthora nicotianae (Blaya i wsp. 2016) oraz Phytophthora infestans (Ristaino i wsp. 2020) w nasionach, tkankach roślinnych oraz glebie. W badaniach nad Tilletia spp. test ddPCR wykorzystany był do wykrywania obecności teliospor Tilletia controversa w glebie (Liu i wsp. 2020). W literaturze brak jednak jakichkolwiek doniesień na temat zastosowania tej techniki do wykrywania DNA Tilletia spp. w tkankach roślin.

Celem niniejszej pracy była ocena możliwości zastosowania testu ddPCR $\mathrm{w}$ detekcji porażenia pszenicy przez T. caries oraz T. laevis we wczesnych stadiach rozwojowych roślin.

\section{Materiały i metody / Materials and methods}

Badania prowadzono w roku 2019 na pszenicy ozimej odmiany Nadobna, którą inokulowano teliosporami T. caries oraz T. laevis, w ilości $0,2 \mathrm{~g}$ teliospor na $100 \mathrm{~g}$ ziarna (EPPO 2004). W celu pozyskania teliospor, z porażonych kłosów pszenicy wyłuskiwano zmienione chorobowo ziarniaki (tzw. sorusy), rozgniatano je w moździerzu i przesiewano przez gazę młyńską, żeby oddzielić fragmenty okrywy owocowo-nasiennej od masy zarodników. Ziarno wysiano do gruntu na mikropoletkach w kształcie koła o średnicy $32 \mathrm{~cm}$, na terenie Instytutu Ochrony Roślin Państwowego Instytutu Badawczego w Poznaniu. Na każdym mikropoletku wysiewano $4 \mathrm{~g}$ ziarna. Kontrolę negatywną stanowiły rośliny wyhodowane $\mathrm{z}$ nieinokulowanego ziarna zaprawionego przedsiewnie środkiem zawierającym karboksynę i tiuram. W 10 wybranych fazach rozwojowych pszenicy: od BBCH 10 (szpilkowanie) do $\mathrm{BBCH} 32$ (drugie kolanko) oraz BBCH 75 (pełna dojrzałość mleczna ziarniaków) pobierano rośliny do dalszych badań molekularnych. W celu zapewnienia odpowiedniej ilości materiału do analiz, w pierwszych pięciu terminach poboru (faza BBCH: $10,11,12,12 / 13$ i 13), gdy pszenica była bardzo mała, wykopywano po 12 roślin, a w kolejnych terminach (od fazy BBCH 21) po 5. Część nadziemną oddzielono od korzeni, suszono, a następnie mielono na jednolitą masę. Dla roślin w fazie BBCH 75 przygotowano osobno próby tkanek zielonych (liście i źdźbła) oraz kłosów. Z każdej próby do izolacji DNA pobierano po $100 \mathrm{mg}$ tkanki. Dodatkowo pod koniec sezonu wegetacyjnego wykonano wizualną ocenę stopnia porażenia kłosów przez Tilletia spp. W tym celu z mikropoletek zebrano wszystkie kłosy. Każdy kłos przecinano w kilku miejscach (co około 1-2 cm) i sprawdzano, czy na przekroju ziarniaków widoczne są objawy porażenia (brunatno-czarna masa teliospor). Następnie obliczono procent porażonych kłosów na mikropoletku. 
Izolację DNA przeprowadzono ze $100 \mathrm{mg}$ zhomogenizowanej tkanki roślinnej przy użyciu zestawu Plant/Fungi DNA isolation Kit (Norgen Biotek), zgodnie z zaleceniami producenta. Jakość oraz stężenie wyizolowanego DNA określono spektrofotometrycznie (NanoDrop, Thermo Fisher Scientific). DNA wyizolowano także z $100 \mathrm{mg}$ zhomogenizowanych ziarniaków porażonych przez Tilletia spp. - stanowiły one kontrolę pozytywną w reakcji ddPCR.

Test ddPCR wykonano w $20 \mu \mathrm{l}$ mieszaniny reakcyjnej zawierającej $10 \mu \mathrm{l}$ 2X QX200 EvaGreen Supermix (Bio$\mathrm{Rad}$ ), 0,2 $\mu 1$ mieszaniny starterów forward (TILf) i reverse (TILr) o stężeniu $10 \mu \mathrm{M}$ specyficznych dla rejonu ITS 1 (Internal Transcribed Spacer) rybosomalnego DNA Tilletia spp. (Kochanová i wsp. 2004), 1 l DNA i uzupełniono wodą do objętości końcowej. Reakcję prowadzono zgodnie z zaleceniami producenta wykorzystując platformę Bio-Rad ddPCR. W pierwszym etapie całość mieszaniny reakcyjnej $(20 \mu \mathrm{l})$, dla każdej analizowanej próby, przeniesiono na przeznaczone do tego celu komercyjne płytki, dodano $70 \mu \mathrm{l}$ oleju QX200"TM Droplet Generation Oil for EvaGreen (Bio-Rad) i z użyciem generatora QX200 Droplet Generator (Bio-Rad) przygotowano emulsję, składającą się z tysięcy kropel. Następnie pobierano $40 \mu \mathrm{l}$ emulsji dla każdej $\mathrm{z}$ badanych prób i przeprowadzono w niej reakcję PCR, z użyciem termocyklera C1000Touch Thermal Cycler
(Bio-Rad). W kolejnym etapie sczytano sygnał fluorescencji we wszystkich badanych próbach z użyciem czytnika QX200 Droplet Reader (Bio-Rad) i stosując oprogramowanie QuantaSoft, korzystające z formuły Poissona, obliczono absolutną liczbę kopii DNA grzyba.

\section{Wyniki i dyskusja / Results and discussion}

Przeprowadzona analiza ddPCR wskazała obecność DNA patogenu w tkankach roślinnych już od fazy rozwojowej BBCH 10 (próba Tz 1). Na podstawie uzyskanych wyników możliwe było również prześledzenie dynamiki namnażania DNA grzyba w tkankach gospodarza w trakcie cyklu rozwojowego roślin (rys. 1, tab. 1). W fazie BBCH 10 (Tz 1) wykazano 6,1 kopii DNA patogenu na $1 \mu 1$ mieszaniny reakcyjnej. Z kolei najwyższą liczbę kopii DNA patogenu odnotowano w fazach BBCH 12 (Tz 3) oraz 30 (Tz 7), odpowiednio 17,3 oraz 20,2 kopii/ $\mu$ l. Uzyskane wyniki nie mogą stanowić jednak prostej zależności namnażania DNA patogenu w tkance roślinnej, wpływać na to mogła zarówno szybko przyrastająca masa tkanek rośliny, jak również możliwość błędu spowodowana różnicami w proporcjach roślin zainfekowanych/zdrowych pobranych do izolacji DNA. Średnia liczba kłosów porażonych przez Tilletia spp. na mi-

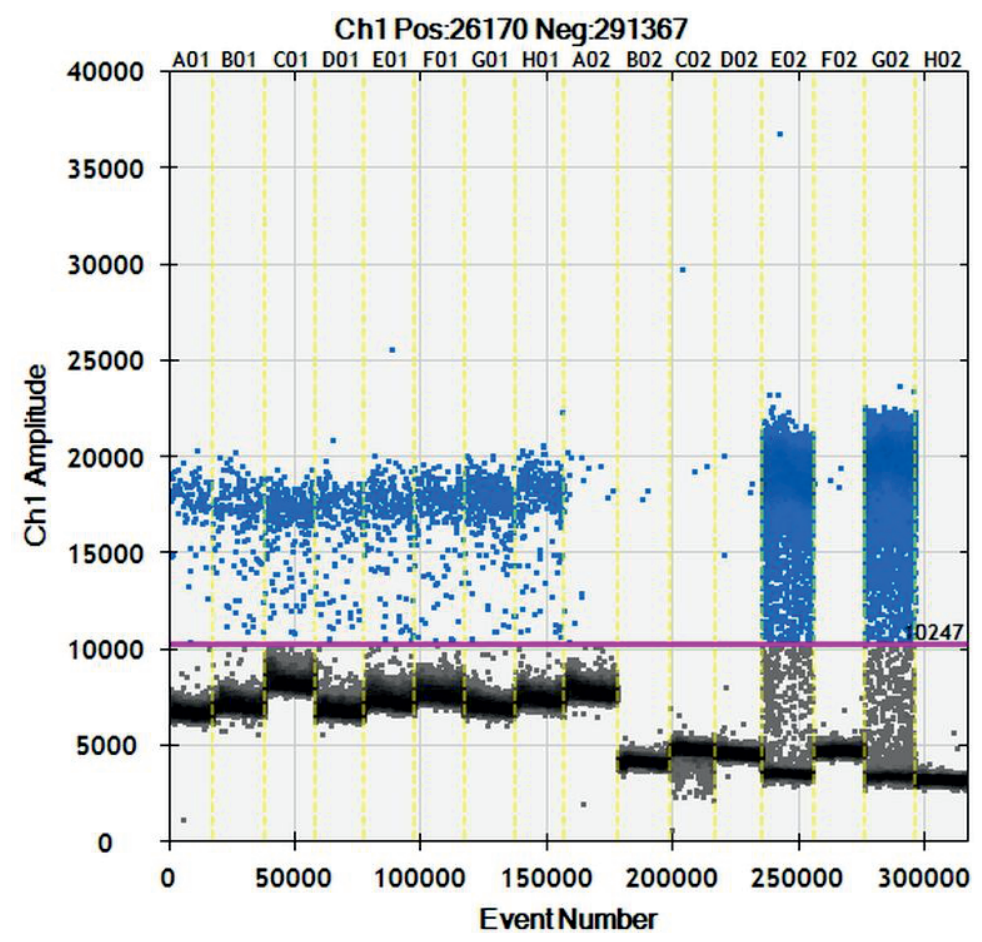

Na osi Y - amplituda fluorescencji kropel pozytywnych (niebieskie) oraz negatywnych (szare) oraz na osi X - liczba zdarzeń. Diagram wygenerowany z użyciem QuantaSoft software (Bio-Rad). Od lewej próby Tz 1, Tz 2, Tz 3, Tz 4, Tz 5, Tz 6, Tz 7, Tz 8, Tz 9, Tn liście, Tn kłos, Tz liście, Tz kłos, kontrola negatywna, kontrola pozytywna

On the $Y$ axis - amplitude of fluorescence of positive (blue) and negative (gray) droplets and on the $X$ axis - number of events. Diagram generated using QuantaSoft software (Bio-Rad). From left samples: Tz 1, Tz 2, Tz 3, Tz 4, Tz 5, Tz 6, Tz 7, Tz 8, Tz 9, Tn leaves, Tn ear, Tz leaves, Tz ear, negative control, positive control

Rys. 1. Detekcja Tilletia spp. techniką ddPCR

Fig. 1. Detection of Tilletia spp. using the ddPCR technique 
Tabela 1. Liczba kopii DNA patogenu w $1 \mu 1$ reakcji oraz w $20 \mu$ całej mieszaniny reakcyjnej obliczona na podstawie liczby kropel pozytywnych oraz negatywnych z zastosowaniem formuły statystycznej Poissona

Table 1. The number of DNA copies of the pathogen in $1 \mu$ reaction and in $20 \mu \mathrm{l}$ of the entire reaction mixture calculated on the basis of the number of positive and negative drops using the Poisson statistical formula

\begin{tabular}{|c|c|c|c|c|c|}
\hline $\begin{array}{l}\text { Oznaczenie próby } \\
\text { Sample designation }\end{array}$ & $\begin{array}{l}\text { Faza rozwojowa rośliny } \mathrm{BBCH} \\
\text { Plant development phase } \mathrm{BBCH}\end{array}$ & $\begin{array}{c}\text { Liczba kopii DNA } \\
\text { patogenu na } 1 \mu 1 \\
\text { Number of the pathogen } \\
\text { DNA copies per } 1 \mu \mathrm{l}\end{array}$ & $\begin{array}{c}\text { Liczba kopii DNA } \\
\text { patogenu na } 20 \mu \mathrm{l} \\
\text { Number of the pathogen } \\
\text { DNA copies per } 20 \mu \mathrm{l}\end{array}$ & $\begin{array}{l}\text { Wyniki } \\
\text { pozytywne } \\
\text { Positive } \\
\text { results }\end{array}$ & $\begin{array}{l}\text { Wyniki } \\
\text { negatywne } \\
\text { Negative } \\
\text { results }\end{array}$ \\
\hline $\mathrm{Tz} 1$ & $\begin{array}{c}10 \text { (szpilkowanie) } \\
\text { (first leaf through coleoptile) }\end{array}$ & 6,1 & 122 & 94 & 18079 \\
\hline Tz 2 & $\begin{array}{l}11 \text { (faza pierwszego liścia) } \\
\text { (first leaf unfolded) }\end{array}$ & 10,6 & 212 & 182 & 20183 \\
\hline $\mathrm{Tz} 3$ & $\begin{array}{l}12 \text { (faza drugiego liścia) } \\
\text { (second leaf unfolded) }\end{array}$ & 17,3 & 346 & 294 & 19855 \\
\hline $\mathrm{Tz} 4$ & $\begin{array}{l}\text { 12/13 (faza pośrednia między } \\
\text { BBCH } 12 \text { i 13) } \\
\text { (intermediate growth stage } \\
\text { between BBCH } 12 \text { and } 13 \text { ) }\end{array}$ & 10,2 & 204 & 169 & 19378 \\
\hline Tz 5 & $\begin{array}{l}13 \text { (faza trzeciego liścia) } \\
\text { (third leaf unfolded) }\end{array}$ & 11,7 & 234 & 197 & 19671 \\
\hline Tz 6 & $\begin{array}{l}21 \text { (początek krzewienia) } \\
\text { (beginning of tillering) }\end{array}$ & 11,7 & 234 & 194 & 19429 \\
\hline Tz 7 & $\begin{array}{l}30 \text { (początek wzrostu źdźbła) } \\
\text { (beginning of stem elongation) }\end{array}$ & 20,2 & 404 & 348 & 20107 \\
\hline Tz 8 & $\begin{array}{l}31 \text { (faza pierwszego kolanka) } \\
\text { (first node stage) }\end{array}$ & 15,3 & 306 & 252 & 19233 \\
\hline Tz 9 & $\begin{array}{l}32 \text { (faza drugiego kolanka) } \\
\text { (second node stage) }\end{array}$ & 0,83 & 16,6 & 15 & 21253 \\
\hline $\begin{array}{l}\text { Tn liście } \\
\text { Tn leaves }\end{array}$ & $\begin{array}{l}75 \text { (pełna dojrzałość } \\
\text { mleczna ziarniaków) } \\
\text { (medium milk) }\end{array}$ & 0,11 & 2,2 & 2 & 20556 \\
\hline $\begin{array}{l}\text { Tn kłos } \\
\text { Tn ear }\end{array}$ & 75 & 0,2 & 4 & 3 & 17731 \\
\hline $\begin{array}{l}\text { Tz liście } \\
\text { Tz leaves }\end{array}$ & 75 & 0,25 & 5 & 4 & 19193 \\
\hline $\begin{array}{l}\text { Tz kłos } \\
\text { Tz ear }\end{array}$ & 75 & 971 & 19420 & 11329 & 8826 \\
\hline $\begin{array}{l}\text { Kontrola negatywna } \\
\text { Negative control }\end{array}$ & 75 & 0,23 & 4,6 & 4 & 20298 \\
\hline $\begin{array}{l}\text { Kontrola pozytywna } \\
\text { Positive control }\end{array}$ & 75 & 1219 & 24380 & 13083 & 7198 \\
\hline
\end{tabular}

$\mathrm{Tz}$ - rośliny zakażane - infected plants, Tn - rośliny niezakażane - uninfected plants

kropoletkach inokulowanych, z których pobierano rośliny do analiz wynosiła 48,3\%. W fazie rozwojowej BBCH 32 ( $\mathrm{Tz}$ 9) stężenie DNA patogenu w tkankach roślin gwałtownie spadło - 0,83 kopii/ $\mu \mathrm{l}$. W fazie BBCH 75 możliwość detekcji DNA patogenu w liściach i źdźbłach pozostawała w granicach błędu - 0,25 kopii DNA/ $\mu$ l, podczas gdy w kłosach odnotowano 971 kopii DNA patogenu/ $\mu$ l, co było skorelowane z rozwojem choroby w ziarniakach. Gwałtowny spadek stężenia DNA patogenu obserwowany w fazie BBCH 32 mógł być skorelowany z rozpoczęciem zasiedlania zawiązków kłosów, stanowiących w tej fazie jedynie niewielki ułamek masy badanych tkanek roślinnych. W ro- ślinach kontrolnych (Tn liście i Tn kłos) w fazie BBCH 75 praktycznie nie odnotowano DNA patogenu zarówno w tkankach liści i łodyg $(0,11$ kopii DNA/ $\mu \mathrm{l})$ oraz kłosów $(0,2$ kopii/ $\mu 1)$. Śladowe ilości DNA patogenu mogą pochodzić zarówno z zanieczyszczeń powstałych podczas pobierania i przygotowania prób, jak i bardzo niskiego poziomu kolonizacji roślin kontrolnych przez Tilletia spp.

Uzyskane wyniki wskazują, że ddPCR jest techniką pozwalającą na ilościowe oznaczenie patogenów obligatoryjnych we wczesnych stadiach porażenia roślin. Czułość testu ddPCR może być porównywalna lub nawet przewyższać wyniki uzyskiwane w dotychczas stosowanych analizach, 
takich jak PCR czy real-time PCR (Dupas i wsp. 2019; Liu i wsp. 2020). Liu i wsp. (2020) porównali zastosowanie PCR, real-time PCR oraz ddPCR do jakościowego i ilościowego pomiaru stężenia teliospor T. controversa w glebie. Wyniki ich badań wskazują, że technika ddPCR pozwalała na detekcję 2,1 kopii DNA patogenu/ $\mu$ l, podczas gdy technika real-time PCR pozwoliła na wykrycie 7,97 kopii DNA/ $\mu$ l. Natomiast konwencjonalny PCR okazał się 100-krotnie mniej czuły niż PCR w czasie rzeczywistym. W niedawno opublikowanych badaniach Yao i wsp. (2019) wykazano, że granica wykrywalności DNA T. laevis, wyizolowanego z teliospor, techniką real-time PCR (SYBR Green I) z zastosowaniem starterów SCAR wynosiła 10 fg/ $\mu 1 \mathrm{DNA}$. Z kolei Zouhar i wsp. (2010) udowodnili, że granica wykrywalności DNA grzyba wynosiła 100 fg DNA Tilletia spp., co odpowiadało 0,22 ng grzybni. Dodatkowo grupa naukowców zidentyfikowała DNA patogenu w merystemach wierzchołkowych pszenicy, wykazując że pobrane tkanki roślinne zawierały od $0,34 \mathrm{ng}$ do $15 \mu \mathrm{g}$ grzybni.

\section{Wnioski / Conclusions}

1. Przeprowadzona analiza ddPCR wskazała możliwość detekcji DNA patogenu od fazy BBCH 10 (szpilkowanie) do fazy BBCH 32 (faza drugiego kolanka).

2. Test ddPCR jest techniką, która ze względu na wysoką czułość i niską podatność na inhibitory roślinne może być szczególnie przydatna $\mathrm{w}$ badaniach prób środowiskowych oraz rolniczych, w tym w diagnostyce porażenia roślin przez patogeny we wczesnych fazach rozwoju choroby.

\section{Literatura / References}

Blaya J., Lloret E., Santísima-Trinidad A.B., Ros M., Pascual J.A. 2016. Molecular methods (digital PCR and real-time PCR) for the quantification of low copy DNA of Phytophthora nicotianae in environmental samples. Pest Management Science 72 (4): $747-753$. DOI: $10.1002 /$ ps.4048

Del Pilar Martínez-Diz M., Andrés-Sodupe M., Berbegal M., Bujanda R., Díaz-Losada E., Gramaje D. 2020. Droplet digital PCR technology for detection of Ilyonectria liriodendri from grapevine environmental samples. Plant Disease104 (4): 1144-1150. DOI: 10.1094/PDIS-03-19-0529-RE

Dreo T., Pirc M., Ramšak Ž., Pavšič J., Milavec M., Žel J., Gruden K. 2014. Optimising droplet digital PCR analysis approaches for detection and quantification of bacteria: a case study of fire blight and potato brown rot. Analytical and Bioanalytical Chemistry 406: 6513-6528. DOI: 10.1007/s00216-014-8084-1

Dumalasová V., Bartoš P. 2006. Wheat reaction to common bunt in the field and in the greenhouse. Czech Journal of Genetics and Plant Breeding 42 (Special Issue): $37-41$.

Dupas E., Legendre B., Olivier V., Poliakoff F., Manceau C., Cunty A. 2019. Comparison of real-time PCR and droplet digital PCR for the detection of Xylella fastidiosa in plants. Journal of Microbiological Methods 162: 86-95. DOI: 10.1016/j.mimet.2019.05.010

EPPO 2004. EPPO Standards PP 1/19(4). Seed-borne cereal fungi. Bulletin OEPP/EPPO Bulletin 34 (1): 5-8. DOI: 10.1111/j.13652338.2004.00691.x

Gao Y., Tan M.K., Zhu Y.G. 2016. Rapid and specific detection of Tilletia indica using loop-mediated isothermal DNA amplification. Australasian Plant Pathology 45: 361-367. DOI: 10.1007/s13313-016-0422-7

Goates B.J. 1996. Common bunt and dwarf bunt. s. 12-25. W: Bunt and Smut Diseases of Wheat: Concepts and Methods of Disease Management (R.D. Wilcoxson, E.E. Saari, red.). CIMMYT, Mexico City, Mexico, 66 ss.

Gutiérrez-Aguirre I., Rački N., Dreo T., Ravnikar M. 2015. Droplet digital PCR for absolute quantification of pathogens. s. 331-347. W: Plant Pathology. Methods in Molecular Biology Vol. 1302 (C. Lacomme, red.). Humana Press, New York, NY, 352 ss. ISBN $978-$ 1-4939-2619-0. DOI 10.1007/978-1-4939-2620-6

Hindson B.J., Ness K.D., Masquelier D.A., Belgrader P., Heredia N.J., Makarewicz A.J., Bright I.J., Lucero M.Y., Hiddessen A.L., Legler T.C., Kitano T.K., Hodel M.R., Petersen J.F., Wyatt P.W., Steenblock E.R., Shah P.H., Bousse L.J., Troup C.B., Mellen J.C., Wittmann D.K., Erndt N.G., Cauley T.H., Koehler R.T., So A.P., Dube S., Rose K.A., Montesclaros L., Wang S., Stumbo D.P., Hodges S.P., Romine S., Milanovich F.P., White H.E., Regan J.F., Karlin-Neumann G.A., Hindson C.M., Saxonov S., Colston B.W. 2011. Highthroughput droplet digital PCR system for absolute quantitation of DNA copy number. Analytical Chemistry 83 (22): 8604-8610. DOI: $10.1021 / \mathrm{ac} 202028 \mathrm{~g}$

Hoffmann J.A. 1982. Bunt of wheat. Plant Disease 66 (11): 979-986. DOI: 10.1094/PD-66-979

Josefsen L., Christiansen S.K. 2002. PCR as a tool for early detection and diagnosis of common bunt in wheat, caused by Tilletia tritici. Mycological Research 106 (11): 1287-1292. DOI: 10.1017/S0953756202006603

Kendrick E.L., Purdy L.H. 1959. A seedling reaction of wheat indicative of bunt infection. Phytopathology 49: 130-132.

Koch H., Jeschke A., Becks L. 2016. Use of ddPCR in experimental evolution studies. Methods in Ecology and Evolution 7 (3): $340-351$. DOI: $10.1111 / 2041-210 X .12467$

Kochanová M., Zouhar M., Prokinová E., Ryšánek P. 2004. Detection of Tilletia controversa and Tilletia caries in wheat by PCR method. Plant, Soil and Environment 50 (2): 75-77. DOI: 10.17221/3684-PSE

Liu J., Li C., Muhae-Ud-Din G., Liu T., Chen W., Zhang J., Gao L. 2020. Development of the droplet digital PCR to detect the teliospores of Tilletia controversa Kühn in the soil with greatly enhanced sensitivity. Frontiers in Microbiology 11 (Article 4): 1-9. DOI: 10.3389/ fmicb.2020.00004

Lu Y., Zhang H., Zhao Z., Wen C., Wu P., Song S., Yu S., Luo L., Xu X. 2020. Application of droplet digital PCR in detection of seed-transmitted pathogen Acidovorax citrulli. Journal of Integrative Agriculture 19 (2): 561-569. DOI: 10.1016/S2095-3119(19)62673-0

Maksimov I.V., Troshina N.B., Khairullin R.M., Surina O.B., Ganiev R.M. 2002. The effect of the common bunt on the growth of wheat seedlings and calluses. Russian Journal of Plant Physiology 49 (5): 685-689. DOI: 10.1023/A:1020253305191 
Matanguihan J.B., Murphy K.M., Jones S.S. 2011. Control of common bunt in organic wheat. Plant Disease 95 (2): 92-103. DOI: 10.1094/ PDIS-09-10-0620

McNeil M., Roberts A.M.I., Cockerell V., Mulholland V. 2004. Real-time PCR assay for quantification of Tilletia caries contamination of UK wheat seed. Plant Pathology 53 (6): 741-750. DOI: 10.1111/j.1365-3059.2004.01094.x

Mehle N., Dobnik D., Ravnikar M., Pompe Novak M. 2018. Validated reverse transcription droplet digital PCR serves as a higher order method for absolute quantification of Potato virus $Y$ strains. Analytical and Bioanalytical Chemistry 410 (16): 3815-3825. DOI: 10.1007/s00216-018-1053-3

Mehle N., Gregur L., Bogožalec Košir A., Dobnik D. 2020. One-step reverse-transcription digital PCR for reliable quantification of different Pepino mosaic virus genotypes. Plants 9 (3): 326. DOI: 10.3390/plants9030326

Nian S.J., Yuan Q., Yin Y.P., Cai J., Wang Z.K. 2009. Detection of Tilletia controversa Kühn by real time quantitative PCR. Scientia Agricultura Sinica 42 (12): 4403-4410. DOI: 10.3864/j.issn.0578-1752.2009.12.036

Pandey B., Mallik I., Gudmestad N.C. 2020. Development and application of a real-time reverse-transcription PCR and droplet digital PCR assays for the direct detection of Potato mop top virus in soil. Phytopathology 110 (1): 58-67. DOI: 10.1094/PHYTO-05-190185-FI

Pieczul K., Perek A., Kubiak K. 2018. Detection of Tilletia caries, Tilletia laevis and Tilletia controversa wheat grain contamination using loop-mediated isothermal DNA amplification (LAMP). Journal of Microbiological Methods 154: 141-146. DOI: 10.1016/j. mimet.2018.10.018

Rački N., Dreo T., Gutierrez-Aguirre I., Blejec A., Ravnikar M. 2014. Reverse transcriptase droplet digital PCR shows high resilience to PCR inhibitors from plant, soil and water samples. Plant Methods 10: 42. DOI: 10.1186/s13007-014-0042-6

Ristaino J.B., Saville A.C., Paul R., Cooper D.C., Wei Q. 2020. Detection of Phytophthora infestans by loop-mediated isothermal amplification, real-time LAMP, and droplet digital PCR. Plant Disease 104 (3): 708-716. DOI: 10.1094/PDIS-06-19-1186-RE

Yao Z., Qin D., Chen D., Liu C., Chen W., Liu T., Liu B., Gao L. 2019. Development of ISSR-derived SCAR marker and SYBR Green I real-time PCR method for detection of teliospores of Tilletia laevis Kühn. Scientific Reports 9: 17651. DOI: 10.1038/s41598-01954163-5

Zhao Y., Xia Q., Yin Y., Wang Z. 2016. Comparison of droplet digital PCR and quantitative PCR assays for quantitative detection of Xanthomonas citri subsp. citri. PLoS One 11 (7): e0159004. DOI: 10.1371/journal.pone.0159004

Zouhar M., Mazáková J., Prokinová E., Váňová M., Rysanek P. 2010. Quantification of Tilletia caries and Tilletia controversa mycelium in wheat apical meristem by real-time PCR. Plant Protection Science 46 (3): 107-115. DOI: 10.17221/50/2009-PPS 